\title{
Gene segregation in gynogenetic brown trout (Salmo trutta L.) : systematically high frequencies of post-reduction
}

\author{
R. GUYOMARD \\ I.N.R.A., Laboratoire de Génétique des Poissons, \\ Centre National de Recherches Zootechniques \\ F 78350 Jouy-en-Josas
}

\begin{abstract}
Summary
The post-reduction rates of 12 protein loci were measured in gynogenetic lines of brown trout obtained by retention of the second polar body. Post-reduction occurs frequently at all the loci (average rate $=0.88 \pm 0.16$ ) and is systematic at 7 of them. Similar results were previously observed in rainbow trout and complete interference could be a common feature in salmonids. The relationship between the degree of divergence of the duplicated loci and their recombination rate is also examined and discussed.
\end{abstract}

Key words : Protein loci, post-reduction, gynogenesis, Salmo trutta $L$.

\section{Résumé}

Ségrégation génique dans des lignées gynogénétiques de truite fario (Salmo trutta L.) : fréquences de post-réduction systématiquement élevées

Les taux de post-réduction de 12 locus enzymatiques ont été estimés dans des lignées gynogénétiques de truite fario obtenues par rétention du $2^{\mathrm{e}}$ globule polaire. La post-réduction se produit fréquemment à tous les locus (taux moyen $=0,88 \pm 0,16$ ) et systématiquement à 7 d'entre eux. Des résultats similaires ont déjà été obtenus chez la truite arc-en-ciel ; l'interférence totale pourrait donc être une caractéristique commune à tous les salmonidés. La relation entre le degré de divergence des locus dupliqués et leur taux de recombinaison est également examinée et discutée.

Mots clés : Polymorphisme enzymatique, post-réduction, gynogénèse, Salmo trutta $L$.

\section{Introduction}

Gynogenesis is the development of an egg triggered by a genetically inactivated spermatozoa. The induction of diploid gynogenesis in vertebrates (review by CHOURROUT, 1982) results in inbreeding and original sex ratios (all-female progenies in female 
homogametic species). The artificial induction of viable gynogenetics is normally achieved by suppression of the second meiotic disjunction. Therefore, the level of inbreeding will depend directly on the post-reduction frequencies which reflect the recombination rate between genes and their centromeres. Gynogenetic lines thus produced have permitted the estimation of the post-reduction rates of loci coding for Mendelian traits (body color, pigmentation pattern, enzyme systems, sex) in several amphibian and fish species (reviewed in this paper). In salmonids, only rainbow trout has been studied and the data clearly showed that high post-reduction rates occurred at some loci in this species (ThorgaARd et al., 1983 ; Guyomard, 1984 ; ThOMPSON \& ScotT, 1984). This report shows that post-reduction is also highly frequent in brown trout and occurs systematically at 7 of 12 loci studied.

\section{Material and methods}

Brown trout eggs and sperm were supplied by the experimental hatchery of Gournay. The experimental design was the same as that described for rainbow trout (GuYomARD, 1984). Seven diploid gynogenetic lines issuing from individual mothers were produced by heat shock according to CHOURRout \& Quillet (1982). Sperm inactivation was obtained by cobalt-60 irradiation (135 Krad, CHOURrout, 1980, 1984). A small number of eggs fertilized with irradiated sperm were not heat-shocked so as to obtain a haploid control. Full-sib controls were also produced in order to check for the maternal genotypes. Full-sib controls and gynogenetic lines were reared at $10 \pm 1{ }^{\circ} \mathrm{C}$ and the survival rates were recorded until the analysis stage.

Ten enzyme systems, involving 12 gene loci, usually polymorphic in brown trout hatchery strains (KRIEG \& GUYOMARD, 1985) were examined : AAT (Aspartate amino transferase), CPK (Creatine phosphokinase), FDP (Fructose diphosphatase), FUM (Fumarase), IDH (Isocitrate dehydrogenase), MDH (Malate dehydrogenase), 6-PGDH (6-Phosphogluconate dehydrogenase), PMI (Phosphomannose isomerase), PGI (Phosphoglucose isomerase), SDH (Sorbitol dehydrogenase). Electrophoretic and staining procedures were given in GuYomaRD \& KRIEG (1983), and KRIEG \& GuYomard (1985). The genetic basis of these systems was described in these papers and verified through inheritance studies (except for FUM, 6-PGDH and PGI) by KRIEG (1984). Males used for full-sib controls and females were analysed for all these loci.

\section{Results}

The survival rates of the gynogenetic lines at the analysis stage are reported in table 1. No hatching was observed in haploid controls.

In order to verify the maternal genotypes for some loci, gene segregations were examined in full-sib matings. Seven loci were examined (Aat-1, Aat-4, Fdp-1, Fum-1, Idh-3, Pgi-2, Sdh-1). In most cases, the number of offsprings studied was small, but sufficient to confirm the maternal genotypes postulated from their electrophoretic pattern (table 2). The electrophoretic patterns and gene segregations observed in family 
TABLE 1

Survival rates in gynogenetic lines.

\begin{tabular}{c|c|c|c|c}
\hline \hline Female & $\begin{array}{c}\text { Initial number } \\
\text { of eggs }\end{array}$ & $\begin{array}{c}\text { Age at analysis } \\
\text { (months) }\end{array}$ & $\begin{array}{c}\text { Survival rate } \\
\text { at analysis }\end{array}$ \\
\hline 3 & 1154 & 4.5 & $41 \%(44 \%){ }^{*}$ \\
4 & 1396 & 7 & $21 \%(21.5 \%)$ \\
5 & 1204 & 7 & $23 \%(27.8 \%)$ \\
6 & 115 & 4.5 & $23.8 \%(26 \%)$ \\
8 & 1322 & 7 & $31 \%(49 \%)$ \\
9 & 960 & 4.5 & $68 \%(71 \%)$ \\
12 & 580 & 4.5 & $70 \%(74 \%)$ \\
\hline
\end{tabular}

${ }^{*}$ : Between brackets, survival rates expressed in p. 100 of the controls.

9 clearly indicated that muscle FUM is a tetrameric enzyme coded for by 2 loci in brown trout. Table 2 reports the genotypes frequencies observed at Fum- 1 in full-sib family 9 assuming that Fum-1 is polymorphic in male and female and Fum- 2 is fixed for allele 100 .

All the genotypes observed in the gynogenetic lines were in agreement with a strictly maternal inheritance (table 2). Only electromorphs identical to the maternal alleles were found in the gynogenetic lines. The maternal origin of some alleles is obvious. For example, Aat-4 (65) was not found in gynogenetic line 8. So, the irradiated pool of sperm, which was used for all the gynogenetic lines, does not transmit Aat-4 (65). The same remark holds for Cpk-1 (100), Fum-1 (140), Idh-3 (200), Mdh-2 (200), Mdh-3 (75), Pmi-2 (100) and Sdh-1 (- 100). Chourrout (1984) showed that residues of paternal chromatin may be observed in the cells of the all-haploid embryos which result from gamma-irradiation of sperm at $100 \mathrm{krad}$ and more. These residual chromosome fragments are however few (about 2 on the average) and much smaller than any maternal chromosome. Therefore, the transmission and normal expression of paternal allele is unlikely. Furthermore, in the case of a paternal transmission in some gynogenetics, trigenic individuals would be detected by gene dosage effect in electrophoregrams. For example, in the case of 6-PGDH, a dimeric enzyme, trigenic heterozygotes (genotypes : $100 / 100 / 60$ or $100 / 60 / 60$ ) would have electrophoretic patterns with band intensity in a $4: 4: 1$ ratio (alleles 100 and 60 are codominant). Actually, all the heterozygotes exhibited a $1: 2: 1$ ratio identical to the mother pattern and in agreement with a digenic heterozygote genotype. Thus, these heterozygotes result only from recombination events and their frequency corresponds to the recombination rate at 6-pgdh-2. The same reasoning can be applied to all the other loci.

At heterozygous loci, no significant difference between the 2 homozygote frequencies should be detected in the gynogenetic lines. This was tested for Mdh-1 and 6-pgdh2 and no significant deviation from the excepted ratio $(1: 1)$ was observed at each locus (table 2). Therefore the gene segregations in the gynogenetic lines also confirm the maternal genotypes proposed.

Post-reduction frequencies ranged from 0.60 to 1.00 with a mean value of 0.88 (table 2). Lines derived from different heterozygous females were examined for Aat-4 and Idh-3. At each locus, the post-reduction frequencies observed in these different lines did not differ significantly. 


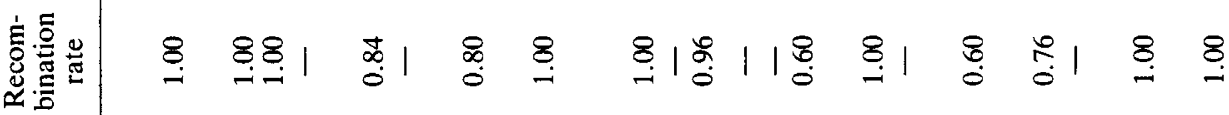

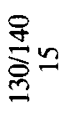

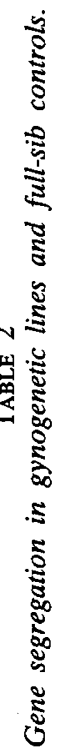

毫然

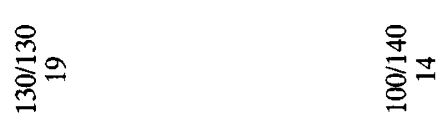

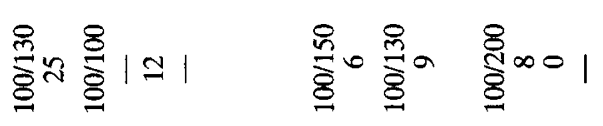

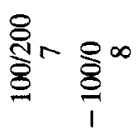

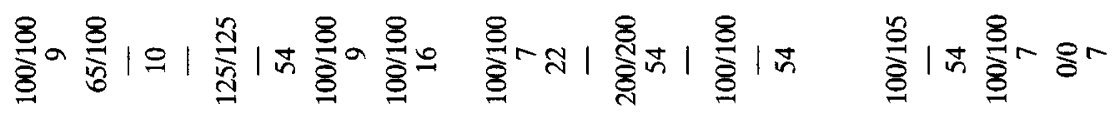

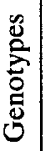

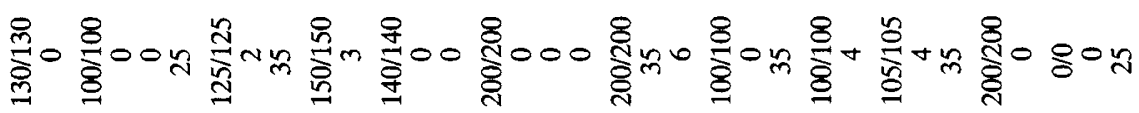

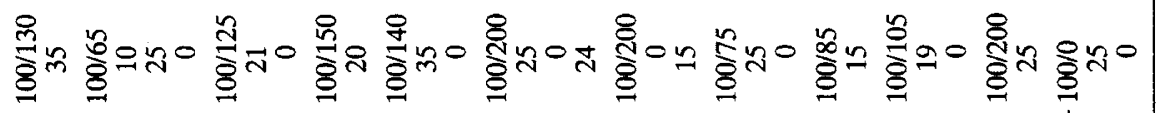

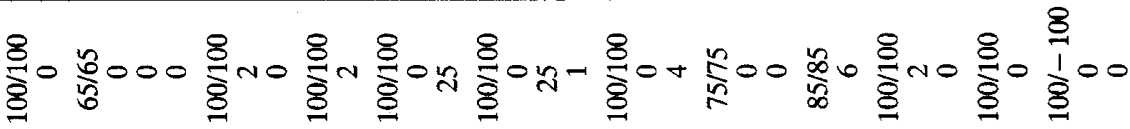

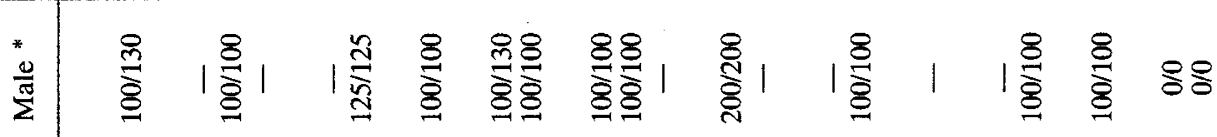

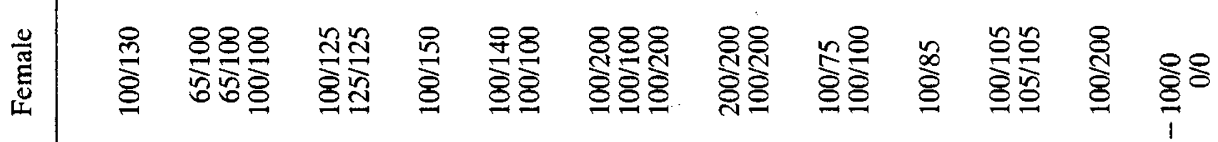

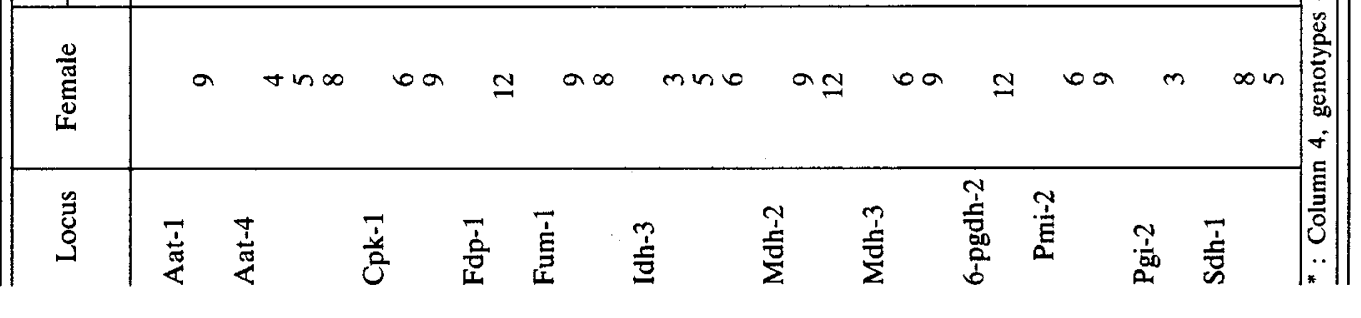




\section{Discussion}

The recombination rates observed in brown trout confirm the results obtained in rainbow trout (ThORgaARd et al., 1983 ; Guyomard, 1984 ; Thompson \& ScoTT, 1984). Post-reduction is highly frequent and occurs systematically at many loci. This could be a general feature of salmonid meïosis. At a given locus, these post-reduction rates generally exhibit little variation between different lines (THORGAARD et al., 1983 ; GuYomARD, 1984 ; this paper). ThOMPSON \& Scotr (1984) found significant variations in heterozygote frequencies at $\mathrm{Mdh}-3,4, \mathrm{Pgm}-2$ and Sod-2,3 in rainbow trout, but the average values obtained by these authors are similar to those observed in the 2 first studies (ThorgaARD et al., 1983 ; GuYOMARD, 1984). Then, we shall consider that the values reported in table 3 for 20 loci are representative of the recombination rate at these loci.

The average recombination rate (r) appears to be higher in brown trout $(r=0.88 \pm 0.16)$ than in rainbow trout $(r=0.68 \pm 0.36)$; however, the standarderrors are still too large in the 2 species to allow accurate comparisons.

\section{TABLE 3}

Relationship between present status of protein loci and recombination rate in brown trout and rainbow trout. For some loci, the status is undetermined and 2 cases are possible, designated by (1) and (2). For example, in brown trout, Cpk-1,2 are considered to be isoloci in case 1 and diverged loci in case 2.

\begin{tabular}{|c|c|c|c|c|c|c|}
\hline \multirow{2}{*}{ Locus } & \multicolumn{2}{|c|}{ Duplicated isoloci } & \multicolumn{2}{|c|}{ Duplicated diverged loci } & \multicolumn{2}{|c|}{ Single loci } \\
\hline & R.T. & B.T. & R.T. & B.T. & R.T. & B.T. \\
\hline $\begin{array}{l}\text { Aat-1,2 } \\
\text { Aat-4 } \\
\text { Agp-2 } \\
\text { Cpk-1 } \\
\text { Est-1 } \\
\text { Fdp-1 } \\
\text { Fum-1,2 } \\
\text { Idh-1,2 } \\
\text { Idh-3,4 } \\
\text { Ldh-4 } \\
\text { Mdh-2 } \\
\text { Mdh-3,4 } \\
\text { 6-pgdh-2 } \\
\text { Pgm-2 } \\
\text { Pgi-2 } \\
\text { Pmi-2 } \\
\text { P-alb-1,2 } \\
\text { Sod-2,3 } \\
\text { Sdh-1 }\end{array}$ & $\begin{array}{c}\text { n.s. } \\
0.60 \dagger \S(1) \\
0.12 \dagger(1) \\
0.95+\S \$\end{array}$ & $\begin{array}{l}0.84(1) \\
1.00 \\
\text { n.s. }\end{array}$ & $\begin{array}{c}0.70 \dagger \S \\
(2) \\
0.02 \dagger \\
(2)\end{array}$ & $\begin{array}{c}(2) \\
\text { n.s. } \\
(2) \\
\\
0.80 \\
\\
1.00 \\
\text { n.s. } \\
0.60\end{array}$ & $\begin{array}{c}0.84 \dagger \\
\text { n.s. } \\
\text { n.s. } \\
\\
\end{array}$ & $\begin{array}{l}1.00(1) \\
\text { n.s. } \\
\text { n.s. } \\
\text { n.s. }\end{array}$ \\
\hline Mean & $\begin{array}{c}0.81^{*} \\
0.98_{+}^{+}\end{array}$ & $\begin{array}{l}=8) \\
=5)\end{array}$ & $\begin{array}{l}0.79 \\
0.77^{+}\end{array}$ & $\begin{array}{r}\text { =9) } \\
11)\end{array}$ & $\begin{array}{l}0.66^{+} \\
0.57^{+}\end{array}$ & $\begin{array}{l}=5) \\
=4)\end{array}$ \\
\hline
\end{tabular}

* : Assuming case (1) for ambiguous loci ${ }_{+}^{+}:$assuming case (2) ; R.T. : rainbow trout ; B.T. : brown trout ; $\mathbf{n}=$ number of loci ; n.s. : not studied; $\dagger:$ data from THORGAARD et al., 1983 ; $\S$ : data from GuYOMARD, 1984 ; $\$$ : data from Thompson \& ScotT (1984). 
In the same way, the available data (table 3) do not allow us to draw conclusions about the degree of differentiation of gene arrangement among species. Each of the 4 loci which received the same designation in the 2 species (Aat-1, Idh-3, Mdh-2, Mdh-3) belongs to a duplicated pair ; a locus studied in one species is not necessarily homologous to its homonym examined in the other species. Therefore, the significant differences observed for Idh-3 $\left(X^{2}=29.8\right)$ and Mdh-2 $\left(X^{2}=6.09\right)$ could reflect structural divergence of homeologous chromosomes (for example, prior speciation) as well as interspecific differentiation at homologous loci. Nevertheless, further studies are likely to reveal differences in recombination rates at homologous loci as a consequence of chromosomal differentiation between species.

Because of the high survival rates observed in some gynogenetic lines, values higher than 66 p. 100 cannot be explained by selection only. If salmonid meiosis is normal (i.e. first division pre-reductional for centromeres), our observations mean that high, or complete, interference is highly frequent in these species ; THORGAARD et al. (1983) suggested that high interference is more common in fish than in other animals and that these differences may be related to the small size of fish chromosome arms. However, the occurence of high recombination rates seems to be similar in amphibians (which have large chromosomes) and in fishes as carp (Cyprinus carpio), plaice (Pleuronectes platessa), zebrafish (Brachydanio rerio) (table 4). On the basis of available data, the dichotomy is not between species having large and small chromosomes, but between salmonids and other species (table 4).

TABLE 4

Recombination values observed in gynogenetic lines of various amphibians and fishes (between brackets, number of loci showing values higher than 0.66 ).

\begin{tabular}{|c|c|c|c|c|}
\hline & $\begin{array}{l}\text { Number } \\
\text { of loci }\end{array}$ & $\begin{array}{c}\text { Range of } \\
\text { recombination } \\
\text { values }\end{array}$ & $\begin{array}{c}\text { Mean } \\
\text { recombination } \\
\text { values }\end{array}$ & References \\
\hline Ambystoma mexicanum & $9(3)$ & $0.12-0.84$ & $0.57 \pm 0.20$ & $\begin{array}{l}\text { LINDSLEY et al. (1956); } \\
\text { ARMSTRONG (1984). }\end{array}$ \\
\hline Rana pipiens & $5(1)$ & $0.16-0.70$ & $0.47 \pm 0.25$ & $\begin{array}{l}\text { NACE et al. }(1970) \\
\text { VoLPE }(1970)\end{array}$ \\
\hline Pleurodeles waltlii .... & $7(3)$ & $0.00-0.79$ & $0.34 \pm 0.39$ & FERRIER (1981). \\
\hline Xenopus laevis . . . . . & $8(3)$ & $0.03-0.80$ & $0.45 \pm 0.29$ & $\begin{array}{l}\text { REINSCHMIDT et al. } \\
\text { (1985). }\end{array}$ \\
\hline Pleuronectes platessa & $5(1)$ & $0.15-0.80$ & $0.42 \pm 0.24$ & THOMPSON (1984). \\
\hline Cyprinus carpio . . . . & $10(3)$ & $0.08-0.97$ & $0.36 \pm 0.33$ & $\begin{array}{l}\text { NAGY \& CSANYI (1982); } \\
\text { LiNHART et al. } \\
\text { (in press); CHERfas } \\
\text { (1977). }\end{array}$ \\
\hline Salmo gairdneri & $14(7)$ & $0.02-1.00$ & $0.68 \pm 0.36$ & $\begin{array}{l}\text { THORGAARD } \text { et al. } \\
\text { (1983); GUYOMARD } \\
\text { (1984); THOMPSON } \\
\text { \& SCOTT (1984). }\end{array}$ \\
\hline Salmo trutta . . . . . . & $12(10)$ & $0.60-1.00$ & $0.88 \pm 0.16$ & This paper. \\
\hline Brachydanio rerio . . . . & $4(1)$ & $0.24-0.89$ & $0.51 \pm 0.28$ & STEISINGER et al. (1986). \\
\hline
\end{tabular}


The salmonid family is of tetraploid origin (OHNo et al., 1969 ; MAY, 1980). Following this tetraploidization, diploidy was reestablished and allowed the duplicated loci to diverge, sometimes until the extinction of one of the 2 copies. The rate of divergence between duplicated loci should depend on the frequency of cross-over between homeologous chromosomes. Isoloci (duplicated loci showing no electrophoretic divergence) should on average be further from the centromere than diverged duplicated loci and single loci (one of the 2 copies lost). In table 3, all the loci examined for recombination are classified according to their present status (isoloci, diverged duplicated loci, single loci). For rainbow trout, their status is that postulated by Allendorf \& THORGAARD (1984). The only change concerned the dimeric form of SOD (another form was found to be tetrameric in brown trout, KRIEG \& GUYOMARD, 1985) which appeared to be coded for by 2 diverged loci in our studies; for brown trout, the genetic determinisms were described in GuYomard \& KrIEg (1983), KRIEG \& Guyomard (1985). The degree of divergence between duplicated loci does not show any clear relation with the recombination rate. One reason could be a mistaken classification of some loci. In brown trout, some doubts remain about Sod-2, Agp-2 and Aat-4 which could belong to pairs of diverged duplicated loci. Aat-1,2, Fum-1,2, Mdh-3,4 and P-alb1,2 always appeared as isoloci in all the salmonid species so far studied. These loci might have retained common alleles through exchange between homeologous chromosomes. Such exchanges were proposed by WrIGHT et al. (1980) to explain unusual inheritance at Mdh-3,4 and Aat-1,2. On the contrary, duplicated loci such as Idh-3,4 and Mdh-1,2 in rainbow trout and Cpk-1,2 in brown trout, could have retained a common allele by chance alone, and not by exchanges between homeologous chromosomes. In several other salmonid species, these duplicated loci have diverged and perhaps should be also considered as diverged duplicated loci in brown trout and rainbow trout. Under these assumptions, the expected relationship is observed (table 3). However, this relation is based on a rather limited number of loci and a speculative interpretation of the divergence at some loci. More recombination data are needed to demonstrate this relationship.

Received January 21, 1986.

Accepted June 24, 1986.

\section{References}

Allendorf F.W., Thorgaard G.M., 1984. Tetraploidy and the evolution of salmonid fishes. In : TURner B.J. (ed), The evolutionary genetics of fishes, 1-53. Plenum, New York.

Armstrong J.B., 1984. Genetic mapping in mexican axolotl, Ambystoma mexicanum. Can. J. Gen. Cytol., 26, 1-6.

Cherfas N.B., 1977. Investigation of radiation-induced diploid gynogenesis in carp. II. Segregation with respect to several morphological characters in gynogenetic progenies. Genetika, 13, $557-$ 562.

Chourrout D., 1980. Thermal induction of diploid gynogenesis and triploidy in rainbow trout (Salmo gairdneri Richardson). Reprod. Nutr. Dev., 20, 727-733.

Chourrout D., 1982. La gynogénèse chez les vertébrés. Reprod. Nutr. Dev., 22, 713-734.

Chourrout D., 1984. Pressure-induced retention of second polar body and suppression of first cleavage in rainbow trout : production of all-triploids, all-tetraploids, and heterozygous and homozygous diploid gynogenetics. Aquaculture, 36, 111-126. 
Chourrout D., Quillet E., 1982. Induced gynogenesis in rainbow trout : sex and survival of progenies. Production of all-triploid populations. Theor. Appl. Genet., 63, 201-205.

Ferrier V., 1981. La gynogénèse expérimentale et son application à l'étude de l'hérédité de divers polymorphismes enzymatiques dans le genre Pleurodeles (amphibiens, urodeles). Thèse de doctorat de sciences naturelles. Université Paul Sabatier, Toulouse.

Guyomard R., 1984. High level of residual heterozygosity in gynogenetic rainbow trout, Salmo gairdneri Richardson. Theor. Appl. Genet., 67, 307-316.

GuYomard R., KRIEG F., 1983. Electrophoretic variation in six populations of brown trout (Salmo trutta L.). Can. J. Genet. Cytol., 25, 403-413.

KRIEG F., 1984. Recherche d'une différentiation génétique entre populations de Salmo trutta. Thèse de $3^{\text {e }}$ cycle, Université de Paris-sud, Orsay.

Krieg F., Guyomard R., 1985. Population genetics of French brown trout (Salmo trutta L.) : large geographical differenciation of wild populations and high similarity of domesticated stocks. Génét. Sél. Evol., 17, 225-242.

Lindsley D.L., Fankhauser G., Humphrey R.R., 1956. Mapping centromeres in the Axolotl. Genetics, 41, 58-64.

Linhart O., Kvasnicka P., Slechtova V., Pokorny J., 1986. Induced gynogenesis by retention of second polar body in common carp. Cyprinus carpio L., and heterozygosity of gynogenetic progeny in trans ferrin and Ldh-B1 loci. Aquaculture (in press).

MAY B., 1980. The salmonid genome : evolutionary restructuring following a tetraploid event. $\mathrm{Ph}$. D. thesis, Pennsylvania state University.

Nace G.W., Richards C.M., Asher J.H., 1970. Parthenogenesis and genetic variability 1. Linkage and inbreeding estimations in the frog Rana pipiens. Genetics, 66, 349-368.

NaGY A., CsanYı V., 1982. Change of genetic parameters in successive gynogenetic generations and some calculations for carp gynogenesis. Theor. Appl. Genet., 63, 105-110.

Ohno S., Muramoto J., Klein J., AtKin N.B., 1969. Diploid - tetraploid relationship in clupeoid and salmonid fish. In : Darlington C.D., Lewis K.R. (ed), Chromosomes today, vol. II, 139 147. Oliver and Boyd, Edinburgh.

Reinschmidt D., friedman J., Hauth J., Ratner E., Cohen M., Miller M., Krotoski D., TOMPKINS R., 1985. Gene-centromere mapping in Xenopus laevis. J. Heredity, 76, 345-347.

Streisinger G., Singer F., Walker C., Knauber D., Dower N., 1986. Segregation analyses and gene-centromere distances in zebrafish. Genetics, 112, 311-319.

Thompson D., 1983. The efficiency of induced diploid gynogenesis in inbreeding. Aquaculture, 33, 237-244.

Thompson D., Scott A.P., 1984. An analysis of recombination data in gynogenetic diploid rainbow trout. Heredity, 53, 441-452.

ThorgaArd G.H., Allendorf F.W., Knudsen K.L., 1983. Gene centromere mapping in rainbow trout : high interference over long map distances. Genetics, 103, 771-783.

Volpe E.P., 1970. Chromosome mapping in the leopard frog. Genetics, 64, 11-21.

Wright J.E., May B., Stoneking M., Lee G.M., 1980. Pseudolinkage of the duplicate loci for supernatant aspartate amino transferase in brook trout, Salvelinus fontinalis. J. Heredity, 71, 223-228. 